\title{
Potential of Salicylic Acid and Synthetic Surfactant on Anthracene and Fluoranthene Remediation by Impatiens Balsamina
}

\author{
Khanitta SOMTRAKOON ${ }^{1, *}$ and Waraporn CHOUYCHAI ${ }^{2}$ \\ ${ }^{1}$ Department of Biology, Faculty of Science, Mahasarakham University, Kantharawichai, \\ Mahasarakham 44150, Thailand \\ ${ }^{2}$ Biology Program, Faculty of Science and Technology, Nakhonsawan Rajabhat University, \\ Nakhonsawan 60000, Thailand
}

('Corresponding author's e-mail: khanitta.s@msu.ac.th)

Received: 12 June 2019, Revised: 8 October 2019, Accepted: 15 November 2019

\begin{abstract}
Plant growth regulators and synthetic surfactants are choices for enhancing the efficiency of PAH phytoremediation. In this study, the use of salicylic acid alone, surfactant alone (Triton X-100 or Tween 80 ), or salicylic acid together with Triton X-100 or Tween 80 on anthracene and fluoranthene removal by Impatiens balsamina were investigated. On days 15 and 30 of the experiment, the spraying of salicylic acid as $0.01 \mathrm{mM}$ and watering of $1 \mathrm{X} \mathrm{CMC}$ of Triton X-100 or Tween 80 were performed. Then, the plant growth parameters and anthracene or fluoranthene remaining in the soil were analyzed on day 45 of the experiment. The results revealed that I. balsamina did not enhance anthracene $(77.4 \%$ remained) and fluoranthene (74.6\% remained) removal when compared with unplanted soil $(63.8 \%$ of anthracene and $70.0 \%$ of fluoranthene remained). Salicylic acid spraying in combination with watering of Triton X-100 (47.1\% anthracene remained) or Tween 80 (59.7\% anthracene remained) enhanced anthracene removal in unplanted soil; however, enhanced fluoranthene removal was not observed. In planted soil, salicylic acid spraying alone, Tween 80 watering alone or salicylic acid spraying in combination with synthetic surfactant (Triton X-100 or Tween 80 ) watering slightly enhanced anthracene removal (54.9-58.0\% of anthracene remained) but not fluoranthene (67.9 - 81.9\% of fluoranthene remained). The results revealed that planting contaminated soil with I. balsamina was not suitable to stimulate anthracene and fluoranthene degradation in this study. Biostimulation of unplanted soil with synthetic surfactant and salicylic acid was suitable to stimulate the removal of anthracene from the soil.
\end{abstract}

Keywords: Anthracene, Fluoranthene, Phytoremediation, Salicylic acid, Triton X-100, Tween 80

\section{Introduction}

Polycyclic aromatic hydrocarbons (PAHs) are a group of persistent organic pollutants, and with their mutagenic and carcinogenic properties, environmental contamination by PAHs is a public concern. The serious problems of PAH contamination are their potential to accumulate in food crops and to biomagnify along the food chain [1]. Contamination by PAHs in soil has been reported worldwide, including a site surrounding a chemical industry in Chongqing (southwest of China) [2], surface soil of industrial area in Yangtze River Delta (eastern of China) [1], and traffic sites in Dhanbad (India) [3]. Soil and sediment contamination by PAHs in Thailand has also been reported $[4,5]$. For example, the mean concentration of 16 PAHs in surface sediment in the Gulf of Thailand was $0.019 \pm 0.015 \mathrm{mg} / \mathrm{kg}$ [4] and the total concentrations of 12 likely carcinogenic PAHs in Khao Lak terrestrial soils (Phang Nga province, Thailand) ranged from $0.004-0.031 \mathrm{mg} / \mathrm{kg}$ [5]. The concentrations of PAHs found in the natural environments of Thailand were lower than the concentration criteria reported by the European classification system of soil contamination, which divided PAH contamination into 4 categories. The 
http://wjst.wu.ac.th

concentration of $\Sigma 16$ PAHs in soil below $0.2 \mathrm{mg} / \mathrm{kg}$ indicates no contamination, while light contamination, moderate contamination, and heavy contamination of $\Sigma 16$ PAHs were $0.2-0.6 \mathrm{mg} / \mathrm{kg}$, $0.6-1.0 \mathrm{mg} / \mathrm{kg}$ and over $1.0 \mathrm{mg} / \mathrm{kg}$, respectively [6]. Soil with heavy PAH contamination is usually found in urban areas with heavy traffic, near oil refineries, and around waste dumpsites [7, 8]. In this study, anthracene and fluoranthene were used as model PAH compounds because both PAHs were on the priority pollutants list by USEPA [1,9], usually found concurrently with other PAHs at various contaminated sites $[2,3,5]$ and have a long half-life in soil (50 - 460 days for anthracene and 44 - 440 days for fluoranthene) [9]. High levels of anthracene and fluoranthene are usually found in industrial areas and waste sites. For example, over $0.002 \mathrm{mg} / \mathrm{kg}$ of anthracene and over $0.04 \mathrm{mg} / \mathrm{kg}$ of fluoranthene were detected in Beijing's topsoil soil [10] and $0.17 \mathrm{mg} / \mathrm{kg}$ of anthracene and $0.91 \mathrm{mg} / \mathrm{kg}$ of fluoranthene were found in municipal waste in India [11]. Soils contaminated with anthracene and fluoranthene pose potential risks to living things because anthracene is a skin sensitizer [12], and the $\mathrm{LD}_{50}$ values of anthracene and fluoranthene to rats by oral administration are $3,200 \mathrm{mg} / \mathrm{kg}$ and $10-30 \mathrm{mg} / \mathrm{kg}$, respectively [13].

Concerns about PAH contamination and its adverse health effects have resulted in extensive studies on the PAH remediation from contaminated soils. Microbial degradation of PAHs is an interesting method to remove PAH from contaminated sites [9]. However, the techniques that rely only on microbial activity have several restrictions that prevent the achievement of remediation, including nutrient restriction, low concentration of degrading microorganisms in contaminated sites, low survival of degrading microorganisms, and low pollutant bioavailability [14]. One way to improve the activity of degrading microorganisms in contaminated soil is plant-assisted bioremediation or phytoremediation, which has been reported to be used in the decontamination of PAHs from contaminated soils [15]. The main mechanism of plants aiding the remediation of hydrophobic organic pollutants is through releasing root exudates to stimulate the degradation of organic pollutants by soil microorganisms [16]. Thus, this study was conducted to determine whether a synergistic interaction between plants and indigenous microbial degraders in the soil will be effective for PAH removal. Another restriction of hydrophobic organic pollutants bioremediation is the low bioavailability of these compounds to plants or degrading microorganisms [17]. Using a surfactant is another way to increase the bioavailability of hydrophobic organic pollutants, including PAH, through accelerating the mass transfer of PAHs from soils to the aqueous phase $[17,18]$. The main purpose of surfactant addition in PAH phytoremediation is to improve the microbial degradation of PAHs in the rhizosphere or the uptake and metabolism of PAH by plants [18]. Thus, the effect of the surfactant used for stimulating the PAH phytoremediation by I. balsamina was investigated in this study. Triton X-100 and Tween 80 were used as representative surfactants because both surfactants have successfully been used to stimulate the degradation of hydrophobic organic pollutants $[19,20]$. For example, Triton X-100 has been used to enhance the degradation of low molecular weight PAHs by indigenous microorganisms [19], and it could promote the cosolubilization of mixed PAHs, such as phenanthrene and pyrene from contaminated soil [20], thus increasing the PAH removal from contaminated soil may be possible. Besides, Tween 80 has a particular interest in the present study due to its low toxicity and high solubilization capacity [21]. Tween 80 has been reported to facilitate the release of hydrophobic organic pollutants from the sorbed phase [8], promote the hydrophobic organic pollutants uptake in plant tissue [17], and facilitate the utilization of hydrophobic organic pollutants by rhizospheric microorganisms [22]. There have been some research studies focusing on surfactant (Triton X-100 and Tween 80) aided PAHs phytoremediation [21,23]. However, a concern about using a surfactant is the wider spread of organic pollutants into other environment compartments [24] but using a surfactant at an appropriate level tends to increase the removal of PAHs from contaminated soils [19]. This may be by reducing the half-life of the PAHs [9] and restricting the widespread of both surfactant and PAHs in the environment.

Moreover, to improve PAH phytoremediation by increasing bioavailability of PAH in the soil through surfactant application, the application of salicylic acid to improve plant growth was also considered in this study. Exogenous salicylic acid has been reported to alleviate the toxicity of pollutants to plants. This characteristic allowed salicylic acid to improve plant growth when planting in 
http://wjst.wu.ac.th

contaminated sites. However, most of the research focused only on using salicylic acid to alleviate the toxicity and protect plants from oxidative stress from metals and metalloids, such as cadmium and arsenic $[25,26]$. A few reports were focusing on using salicylic acid to alleviate the toxicity of organic pollutants. For example, the application of $2 \mathrm{mg} / \mathrm{l}$ of exogenous salicylic acid had the greatest ameliorating effect on chlorpyrifos toxicity in wheat plants. In chlorpyrifos-treated soils, the root and shoot lengths of wheat seedlings treated with $2 \mathrm{mg} / \mathrm{l}$ were increased by 69.2 and $35.9 \%$, respectively, compared with the treatment without salicylic acid. Similarly, salicylic acid at $2 \mathrm{mg} / \mathrm{l}$ increased chlorophyll content in wheat leaves and also reduced the antioxidant stress caused by chlorpyrifos [27]. Previous studies have investigated only the effect of a surfactant or salicylic acid separately to improve the removal of pollutants from contaminated sites. The aim of this study was, therefore, to investigate the roles of surfactant and salicylic acid in combination to improve the growth of the plant and the removal of PAH from contaminated soils. The effect of the simultaneous use of a surfactant (Triton X-100 or Tween 80) and salicylic acid was tested with I. balsamina. The addition of all amendments in anthracene and fluoranthene contaminated soil planted with I. balsamina was expected to improve the growth of the plants and stimulate the removal of both PAHs from the soil. I. balsamina was selected as a model plant in this study because successful petroleum hydrocarbon bioremediation has been reported by the synergistic effect between I. balsamina and a petroleum hydrocarbon-degrading mix of microorganisms $[28,29]$. Moreover, I. balsamina is an ornamental plant that was able to tolerate organic waste when planted in contaminated soil [30]. Thus, the simultaneous removal of PAH and improvement of the landscape at contaminated sites by planting I. balsamina may occur.

\section{Materials and methods}

\section{Soil characteristics and preparation of anthracene and fluoranthene-spiked soil}

Soil without a previous history of PAH contamination was collected from a grassland field near Nakhonsawan Rajabhat University. The soil was sent for the analysis of the physical and chemical characteristics at the Environmental Quality Examining Service Center, Faculty of Environment and Resource Studies, Mahasarakham University, Thailand. The physical and chemical characteristics of this

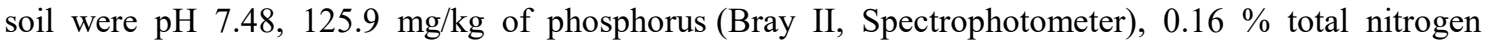
(Kjeldahl method), $2.56 \%$ organic matter (Walkley and Black, 1947), and 1.51\% organic carbon (Walkley and Black, 1947). This soil contained $92 \%$ sand, $4 \%$ silt, and $4 \%$ clay (Titrate method, AOAC). Background levels of anthracene and fluoranthene were not detected in the soil when analyzed by a Gas Chromatography - Flame Ionization Detector (GC-FID). Then, this non-contaminated soil was spiked with solutions of anthracene (Fluka, USA, purity $99 \%$ ) and fluoranthene (Fluka, USA, purity $99 \%$ ) dissolved in dichloromethane to give final concentrations of each $\mathrm{PAH}$ of $100 \mathrm{mg} / \mathrm{kg}$. The anthracene and fluoranthene-contaminated soils were prepared for 60 pots for use in the phytoremediation experiment.

\section{Phytotoxicity of Triton X-100 and Tween 80 on seedlings of I. balsamina}

The phytotoxicity of Triton X-100 and Tween 80 at $1 \mathrm{X}$ CMC and 10X CMC (CMC is the initial concentration of the surfactants at which they form micelles [31]) was determined in plastic cups containing $50 \mathrm{~g}$ of soil spiked with anthracene and fluoranthene at a total concentration of $200 \mathrm{mg} / \mathrm{kg}$ $(100 \mathrm{mg} / \mathrm{kg}$ of each PAH). The experiment was performed factorially in a completely randomized design (2x5). The first factor was a total concentration of anthracene plus fluoranthene in soil $(0$ and $200 \mathrm{mg} / \mathrm{kg})$. The second factor was the level of synthetic surfactant application (0, 1X CMC Triton X-100, 10 X CMC Triton X-100, 1X CMC Tween 80, and 10X CMC Tween 80). The experiment was performed as three replicates and each replicated was cultivated with 10 seeds of $I$. balsamina. After 13 days of seed emergence, Triton X-100 or Tween 80 at each concentration were watered onto the seedlings that were growing in anthracene plus fluoranthene-contaminated soil and non-contaminated soil. Distilled water was added in the same amount as the synthetic surfactant to serve as a control. The phytotoxicity of Triton X-100 and Tween 80 were considered on day 20 of the experiment by the percentage of seedlings surviving, shoot and root length, fresh weight and dry weight of the shoot and root. The concentration of 
http://wjst.wu.ac.th

the surfactant that did not affect the seedling growth of I. balsamina was further used in the phytoremediation experiment.

\section{Phytoremediation experiment}

The phytoremediation experiments were set up using cylindrical plastic pots containing $1 \mathrm{~kg}$ dry weight of soil spiked with anthracene and fluoranthene. The spiked soils were inoculated with I. balsamina seeds (commercial seeds of Chiatai Ltd. Bangkok and prepared by immersing them in distilled water before planting into the spiked soil). To investigate the effect of Triton X-100 or Tween 80 and salicylic acid on anthracene and fluoranthene removal from soil planted with I. balsamina, $10 \mathrm{ml}$ of 1X CMC of Triton X-100 or Tween 80 was added separately to the soil on days 15 and 30 after seed germination. Besides, $5 \mathrm{ml}$ of $0.01 \mathrm{mM}$ salicylic acid was sprayed on days 15 and 30 after seed germination. The experimental design was performed in a completely randomized design and divided into twelve treatments for biodegradation described below. Each treatment was performed in five replicates.

1) Anthracene and fluoranthene-contaminated soil

2) Anthracene and fluoranthene-contaminated soil + Triton $X-100$

3) Anthracene and fluoranthene-contaminated soil + Tween 80

4) Anthracene and fluoranthene-contaminated soil + salicylic acid

5) Anthracene and fluoranthene-contaminated soil + Triton X-100 + salicylic acid

6) Anthracene and fluoranthene-contaminated soil + Tween $80+$ salicylic acid

7) Anthracene and fluoranthene-contaminated soil planted with I. balsamina

8) Anthracene and fluoranthene-contaminated soil + Triton X-100 planted with I. balsamina

9) Anthracene and fluoranthene-contaminated soil + Tween 80 planted with I. balsamina

10) Anthracene and fluoranthene-contaminated soil + salicylic acid planted with I. balsamina

11) Anthracene and fluoranthene-contaminated soil + Triton $X-100+$ salicylic acid planted with I. balsamina

12) Anthracene and fluoranthene-contaminated soil + Tween $80+$ salicylic acid planted with I. balsamina

For plant health measurement, all plants in planted treatments were measured and the two treatments of planting I. balsamina with or without salicylic acid application in non-contaminated soil were set as control.

Distilled water was added every day to each pot to maintain the soil water holding capacity. The experiment was performed for 45 days, then the soil in each pot was thoroughly mixed and $1 \mathrm{~g}$ of soil was collected for anthracene and fluoranthene analysis. Plant samples were also collected and parameters for plant growth were measured: length, fresh weight and dry weights of root and shoot. Chlorophyll a, chlorophyll $\mathrm{b}$ and total chlorophyll contents in the leaves of the plant samples were analyzed and calculated using the equations available in Huang et al. [32].

$[\mathrm{Chl} \mathrm{a}]=[12.7 \times \mathrm{A} 663]-[2.69 \times \mathrm{A} 645]$

$[\mathrm{Chl} \mathrm{b}]=[22.9 \times \mathrm{A} 645]-[4.68 \times \mathrm{A} 663]$

$[$ Total Chl $]=[8.02 \times \mathrm{A} 663]+[20.2 \times \mathrm{A} 645]$

\section{Anthracene extraction and analytical}

Soil and plant samples were subjected to soxhlet extraction according to the method described in Somtrakoon et al. [15]. Briefly, $1 \mathrm{~g}$ samples were mixed with sodium sulfate anhydrous and extracted with the soxhlet extraction apparatus for $8 \mathrm{~h}$. The extracts were reduced in volume in an evaporator, and then the soil and plant extracts were analyzed for anthracene and fluoranthene by GC-FID (Shimadzu, Model GC-2014AFSC). Separation condition was performed using a Rtx®-5MS capillary column $(30 \mathrm{~m}$ $\times 25 \mathrm{~mm}$, I.D. $=25 \mu \mathrm{m}$ ). The helium carrier flow rate was $1.13 \mathrm{ml} / \mathrm{min}$ under the split 13.4:1 ratio condition. The oven temperature was programmed at $150{ }^{\circ} \mathrm{C}$ for $1 \mathrm{~min}$, followed by a linear increase of $12{ }^{\circ} \mathrm{C} / \mathrm{min}$ to $280^{\circ} \mathrm{C}$. The detector temperature was maintained at $320{ }^{\circ} \mathrm{C}$. 
http://wjst.wu.ac.th

\section{Anthracene and fluoranthene degrader count}

A $1 \mathrm{~g}$ soil sample was placed in $9.0 \mathrm{ml} 0.85 \%(\mathrm{w} / \mathrm{v})$ normal saline solution and shaken at $180 \mathrm{rpm}$ for $2 \mathrm{~h}$. The suspension was serially diluted and plated on a mineral salts medium containing per liter: 10 $\mathrm{mM} \mathrm{Na}_{2} \mathrm{HPO}_{4} / \mathrm{KH}_{2} \mathrm{PO}_{4}$ buffer, $\mathrm{pH} 7.2 ;\left(\mathrm{NH}_{4}\right)_{2} \mathrm{SO}_{4}, 2.38 \mathrm{~g} ; \mathrm{MgSO}_{4} .7 \mathrm{H}_{2} \mathrm{O}, 0.25 \mathrm{~g} ; \mathrm{NaCl}, 0.50 \mathrm{~g} ; 0.010 \mathrm{M}$ $\mathrm{FeSO}_{4} .7 \mathrm{H}_{2} \mathrm{O}, 0.2 \mathrm{ml}$; and $20 \mathrm{mM} \mathrm{CaCl}, 5.0 \mathrm{ml}$ [33]. Then $1 \%(\mathrm{w} / \mathrm{v})$ of anthracene or fluoranthene dissolve in diethyl ether was sprayed on the surface of the medium. The diethyl ether was allowed to evaporate at room temperature $\left(28-30^{\circ} \mathrm{C}\right)$ inside a fume hood. Plates were incubated for seven days and the colonies with clear zones were counted as the number of anthracene or fluoranthene degraders.

\section{Statistical analysis}

Two-way ANOVA was used to test for statistical significance among treatments of the surfactant toxicity to seedlings and PAH biodegradation. One-way ANOVA was used to test for statistical significance among treatments of phytotoxicity in the phytoremediation experiment. The LSD method was used for subsequent multiple comparisons of means.

\section{Results and discussion}

General characteristics of I. balsamina grown in anthracene and fluoranthene-contaminated soil

The phytotoxicity of non-ionic surfactant including Triton X-100 and Tween 80 at $1 \mathrm{X}$ CMC and 10X CMC was determined first to select a suitable concentration of the surfactant to be used in the phytoremediation experiment. The results revealed that the percentage of seedling survival of $I$. balsamina grown in the non-contaminated soil was not different from that of those grown in anthracene plus fluoranthene-contaminated soil. The presence of Triton X-100 and Tween 80 in the soil did not decrease the percentage of survival in the seedlings of I. balsamina grown in non-contaminated soil and anthracene plus fluoranthene-contaminated soil (Data not shown). Even though, the addition of Triton X100 or Tween 80 at $1 \mathrm{X} \mathrm{CMC}$ and 10X CMC to anthracene plus fluoranthene-contaminated soil did not affect the shoot length, shoot fresh weight, shoot dry weight, and root length of I. balsamina seedlings but the 10X CMC of Triton X-100 tended to decrease the root fresh weight and root dry weight of I. balsamina seedlings grown in anthracene plus fluoranthene-contaminated soil (Table 1 and 2). Thus, only the $1 \mathrm{X}$ CMC of Triton X-100 and Tween 80 were select for use in the phytoremediation experiment. The toxicity of non-ionic surfactants to plants has been reported in the terrestrial plants. For example, the development of meristematic cells at the root tips in barley was inhibited by a non-ionic surfactant [34]. Moreover, the toxicity of the surfactant depended on the surfactant concentration [34]; thus, it is not surprising that $10 \mathrm{X}$ CMC of Triton X-100 was more toxic to I. balsamina than $1 \mathrm{X}$ CMC of Triton X-100.

In the phytoremediation experiment, I. balsamina was planted in soil contaminated with anthracene plus fluoranthene for 45 days. Salicylic acid and surfactants (1X CMC of Triton X-100 or 1X CMC of Tween 80) were added to the soil separately or in combination to stimulate the growth of the plant and PAHs phytoremediation, respectively. The results in Table 3 indicate that the growth of I. balsamina in anthracene and fluoranthene-contaminated soil was normal for the 45 days of the experiment. The application of salicylic acid did not increase the growth of I. balsamina grown in non-contaminated soil or anthracene and fluoranthene-contaminated soil. The application of the surfactant (1X CMC of Triton X-100 or $1 \mathrm{X} \mathrm{CMC} \mathrm{of} \mathrm{Tween} \mathrm{80)} \mathrm{did} \mathrm{not} \mathrm{exert} \mathrm{adverse} \mathrm{effects} \mathrm{on} \mathrm{the} \mathrm{growth} \mathrm{of} \mathrm{I.} \mathrm{balsamina} \mathrm{for} \mathrm{the} 45$ days of the experiment; however, the growth of I. balsamina seemed to decrease in the presence of Triton X-100 when observed by the naked eye (Figure 1 and 2). The toxic effect of Triton X-100 and Tween 80 on the plant may be different and depended on the chemical structure of both surfactants. Triton X-100 exerted a higher toxicity than Tween 80 because the molecules of Triton X-100 contained a benzene ring, branched aliphatic chain and short polyoxyethylene chains [35]. 
Table 1 Toxicity of Triton X-100 on seedling growth of $I$. balsamina grown in anthracene plus fluoranthene-contaminated soil.

\begin{tabular}{|c|c|c|c|c|c|c|}
\hline \multirow[b]{2}{*}{ Surfactant } & \multicolumn{3}{|c|}{ Shoot } & \multicolumn{3}{|c|}{ Root } \\
\hline & $\begin{array}{c}\text { Shoot } \\
\text { length }(\mathrm{cm})\end{array}$ & $\begin{array}{l}\text { Shoot fresh } \\
\text { weight (mg) }\end{array}$ & $\begin{array}{c}\text { Shoot dry } \\
\text { weight (mg) }\end{array}$ & $\begin{array}{c}\text { Root length } \\
(\mathrm{cm})\end{array}$ & $\begin{array}{c}\text { Root fresh } \\
\text { weight (mg) }\end{array}$ & $\begin{array}{c}\text { Root dry } \\
\text { weight (mg) }\end{array}$ \\
\hline \multicolumn{7}{|l|}{ Non-contaminated soil } \\
\hline DW & $5.7 \pm 0.4$ & $250.6 \pm 26.4 \mathrm{~A}$ & $8.5 \pm 1.2 \mathrm{~A}$ & $2.2 \pm 0.2$ & $26.7 \pm 3.6$ & $2.9 \pm 2.3 \mathrm{a}$ \\
\hline Triton X-100 1XCMC & $5.9 \pm 0.5$ & $230.9 \pm 23.5 \mathrm{~A}$ & $8.4 \pm 9.3 \mathrm{~A}$ & $3.3 \pm 0.4$ & $30.4 \pm 6.6$ & $3.9 \pm 0.8 \mathrm{a}$ \\
\hline Triton X-100 10XCMC & $6.0 \pm 0.4$ & $235.4 \pm 30.1 \mathrm{~A}$ & $9.8 \pm 1.3 \mathrm{~A}$ & $3.5 \pm 0.4$ & $23.6 \pm 4.8$ & $2.7 \pm 0.5 \mathrm{a}$ \\
\hline \multicolumn{7}{|l|}{ Anthracene + Fluoranthene } \\
\hline DW & $6.3 \pm 0.6$ & $175.7 \pm 18.9 B$ & $6.1 \pm 0.7 \mathrm{~A}$ & $4.5 \pm 0.6$ & $34.3 \pm 4.7$ & $4.2 \pm 1.0 \mathrm{a}$ \\
\hline Triton X-100 1XCMC & $4.8 \pm 0.4$ & $126.2 \pm 14.4 \mathrm{~B}$ & $5.5 \pm 0.4 \mathrm{~B}$ & $3.6 \pm 0.3$ & $35.4 \pm 7.3$ & $4.6 \pm 0.7 \mathrm{a}$ \\
\hline Triton X-100 10XCMC & $5.6 \pm 0.4$ & $121.4 \pm 9.1 \mathrm{~B}$ & $5.3 \pm 0.4 \mathrm{~B}$ & $2.5 \pm 0.5$ & $17.1 \pm 2.3$ & $2.0 \pm 0.2 b$ \\
\hline PAHs & ns & $* *$ & $* *$ & ns & ns & ns \\
\hline Surfactant & ns & ns & ns & ns & ns & $*$ \\
\hline PAHs*Surfactant & ns & ns & ns & $* *$ & $\mathrm{~ns}$ & ns \\
\hline
\end{tabular}

Different lowercase letters denote significant differences $(\mathrm{P}<0.05)$ between the surfactant concentration in the same soil. Different capital letters denote significant differences $(\mathrm{P}<0.05)$ between the soil with same surfactant concentration. Abbreviation: PAHs $=100 \mathrm{mg} / \mathrm{kg}$ of anthracene plus $100 \mathrm{mg} / \mathrm{kg}$ of fluoranthene; $\mathrm{ns}=$ non-significant difference $(P>0.05) ; *$ significant difference $(P<0.05) ; * *$ significant difference $(P<0.01)$

Table 2 Toxicity of Tween 80 on seedling growth of I. balsamina grown in anthracene plus fluoranthenecontaminated soil.

\begin{tabular}{|c|c|c|c|c|c|c|}
\hline \multirow[b]{2}{*}{ Surfactant } & \multicolumn{3}{|c|}{ Shoot } & \multicolumn{3}{|c|}{ Root } \\
\hline & $\begin{array}{c}\text { Shoot } \\
\text { length }(\mathrm{cm})\end{array}$ & $\begin{array}{l}\text { Shoot fresh } \\
\text { weight }(\mathrm{mg})\end{array}$ & $\begin{array}{c}\text { Shoot dry } \\
\text { weight (mg) }\end{array}$ & $\begin{array}{c}\text { Root length } \\
(\mathrm{cm})\end{array}$ & $\begin{array}{c}\text { Root fresh } \\
\text { weight (mg) }\end{array}$ & $\begin{array}{c}\text { Root dry } \\
\text { weight (mg) }\end{array}$ \\
\hline \multicolumn{7}{|l|}{ Non-contaminated soil } \\
\hline DW & $5.7 \pm 0.4$ & $250.6 \pm 26.4 \mathrm{~A}$ & $8.5 \pm 1.2 \mathrm{~A}$ & $2.2 \pm 0.2 \mathrm{~B}$ & $26.7 \pm 3.6$ & $2.9 \pm 2.3$ \\
\hline Tween 80 1XCMC & $6.1 \pm 0.4$ & $226.4 \pm 24.4 \mathrm{~A}$ & $9.0 \pm 0.9 \mathrm{~A}$ & $3.0 \pm 0.3 \mathrm{~A}$ & $29.1 \pm 4.9$ & $2.8 \pm 0.5$ \\
\hline Tween 80 10XCMC & $6.9 \pm 0.6$ & $275.2 \pm 28.4 \mathrm{~A}$ & $10.5 \pm 1.1 \mathrm{~A}$ & $3.4 \pm 0.3 \mathrm{~A}$ & $48.6 \pm 6.3$ & $2.9 \pm 0.6$ \\
\hline \multicolumn{7}{|l|}{ Anthracene + Fluoranthene } \\
\hline DW & $6.3 \pm 0.6$ & $175.7 \pm 18.9 \mathrm{~B}$ & $6.1 \pm 0.7 \mathrm{~A}$ & $4.5 \pm 0.6 \mathrm{~A}$ & $34.3 \pm 4.7$ & $4.2 \pm 1.0$ \\
\hline Tween 80 1XCMC & $5.4 \pm 0.3$ & $161.3 \pm 14.3 \mathrm{~A}$ & $5.7 \pm 0.5 \mathrm{~B}$ & $3.8 \pm 0.5 \mathrm{~A}$ & $36.7 \pm 5.2$ & $5.3 \pm 1.0$ \\
\hline Tween 80 10XCMC & $5.6 \pm 0.7$ & $142.1 \pm 11.0 \mathrm{~B}$ & $5.3 \pm 0.5 \mathrm{~B}$ & $4.3 \pm 0.4 \mathrm{~A}$ & $30.8 \pm 2.8$ & $2.3 \pm 0.4$ \\
\hline \multirow{3}{*}{$\begin{array}{l}\text { PAHs } \\
\text { Surfactant } \\
\text { PAHs*Surfactant }\end{array}$} & ns & $* *$ & $* *$ & ** & ns & ns \\
\hline & $\mathrm{ns}$ & $\mathrm{ns}$ & ns & $\mathrm{ns}$ & ns & ns \\
\hline & ns & ns & ns & ns & $*$ & ns \\
\hline
\end{tabular}

Different lowercase letters denote significant differences $(\mathrm{P}<0.05)$ between the surfactant concentration in the same soil. Different capital letters denote significant differences $(P<0.05)$ between the soil with same surfactant concentration. Abbreviation: PAHs $=100 \mathrm{mg} / \mathrm{kg}$ of anthracene plus $100 \mathrm{mg} / \mathrm{kg}$ of fluoranthene; ns = non-significant difference $(P>0.05) ; *$ significant difference $(P<0.05) ; * *$ significant difference $(P<0.01)$. 
Table 3 Shoot growth, root growth and chlorophyll content in leaves of I. balsamina grown in anthracene plus fluoranthene-contaminated soil receiving salicylic acid and 1X CMC of Triton X-100 or 1X CMC of Tween 80 .

\begin{tabular}{|c|c|c|c|c|c|c|c|c|c|}
\hline \multirow[b]{2}{*}{ Treatment } & \multicolumn{3}{|c|}{ Shoot growth } & \multicolumn{3}{|c|}{ Root growth } & \multicolumn{3}{|c|}{ Chlorophyll content in leaves } \\
\hline & $\begin{array}{c}\text { Length } \\
\text { (cm) }\end{array}$ & $\begin{array}{c}\text { Fresh weight } \\
\text { (mg) }\end{array}$ & $\begin{array}{l}\text { Dry weight } \\
\text { (mg) }\end{array}$ & $\begin{array}{c}\text { Length } \\
\text { (cm) }\end{array}$ & $\begin{array}{c}\text { Fresh weight } \\
\text { (mg) }\end{array}$ & $\begin{array}{c}\text { Dry weight } \\
\text { (mg) }\end{array}$ & $\begin{array}{c}\text { Chlorophyll a } \\
\text { (mg/ml) }\end{array}$ & $\begin{array}{c}\text { Chlorophyll b } \\
(\mathrm{mg} / \mathrm{ml})\end{array}$ & $\begin{array}{c}\text { Total } \\
\text { chlorophyl } \\
(\mathrm{mg} / \mathrm{ml})\end{array}$ \\
\hline Non-contaminated soil & $25.5 \pm 1.5 \mathrm{a}$ & $4458.0 \pm 889.4 \mathrm{ab}$ & $488.3 \pm 75.2 \mathrm{a}$ & $3.1 \pm 0.5 \mathrm{a}$ & $880.0 \pm 347.9 \mathrm{a}$ & $52.1 \pm 16.6 \mathrm{a}$ & $14.7 \pm 0.4 \mathrm{a}$ & $8.2 \pm 0.8 \mathrm{a}$ & $22.9 \pm 1.2 \mathrm{a}$ \\
\hline Non-contaminated soil $+\mathrm{SA}$ & $20.8 \pm 1.4 \mathrm{ab}$ & $5990.0 \pm 1336.8 \mathrm{a}$ & $314.7 \pm 89.3 b$ & $4.2 \pm 0.5 \mathrm{a}$ & $1674.0 \pm 526.0 \mathrm{a}$ & $68.3 \pm 21.8 \mathrm{a}$ & $10.0 \pm 0.7 \mathrm{a}$ & $5.7 \pm 0.3 \mathrm{a}$ & $15.7 \pm 0.9 \mathrm{a}$ \\
\hline PAHs & $12.6 \pm 1.4 \mathrm{~b}$ & $1546.0 \pm 384.5 b$ & $79.9 \pm 18.8 \mathrm{c}$ & $4.4 \pm 0.8 \mathrm{a}$ & $724.0 \pm 250.5 \mathrm{a}$ & $29.7 \pm 10.1 \mathrm{a}$ & $10.8 \pm 0.1 \mathrm{a}$ & $5.6 \pm 0.3 \mathrm{a}$ & $16.4 \pm 0.2 \mathrm{a}$ \\
\hline $\mathrm{PAHs}+\mathrm{SA}$ & $17.2 \pm 1.4 b$ & $2564.0 \pm 626.9 b$ & $174.5 \pm 26.2 b c$ & $5.6 \pm 0.7 \mathrm{a}$ & $1134.0 \pm 243.7 \mathrm{a}$ & $42.7 \pm 8.0 \mathrm{a}$ & $11.0 \pm 0.2 \mathrm{a}$ & $4.6 \pm 0.2 \mathrm{a}$ & $15.6 \pm 0.1 \mathrm{a}$ \\
\hline PAHs + Triton X-100 & $15.2 \pm 1.6 \mathrm{~b}$ & $1746.0 \pm 278.2 b$ & $86.7 \pm 11.0 \mathrm{c}$ & $3.4 \pm 0.8 \mathrm{a}$ & $520.0 \pm 38.6 \mathrm{a}$ & $22.8 \pm 1.7 \mathrm{a}$ & $8.0 \pm 0.6 \mathrm{a}$ & $5.0 \pm 0.3 \mathrm{a}$ & $13.1 \pm 0.9 \mathrm{a}$ \\
\hline PAHs + Tween 80 & $15.2 \pm 0.8 b$ & $2978.0 \pm 460.8 b$ & $145.3 \pm 20.3 \mathrm{c}$ & $6.4 \pm 1.5 \mathrm{a}$ & $1690.0 \pm 455.8 \mathrm{a}$ & $70.9 \pm 21.2 \mathrm{a}$ & $14.0 \pm 2.5 \mathrm{a}$ & $7.4 \pm 1.1 \mathrm{a}$ & $21.3 \pm 3.6 \mathrm{a}$ \\
\hline PAHs + Triton X-100+ SA & $16.5 \pm 3.2 b$ & $2768.0 \pm 813.5 b$ & $114.7 \pm 31.9 \mathrm{c}$ & $5.3 \pm 0.9 \mathrm{a}$ & $1048.0 \pm 198.9 \mathrm{a}$ & $42.8 \pm 8.0 \mathrm{a}$ & $15.4 \pm 4.3 \mathrm{a}$ & $8.5 \pm 1.9 \mathrm{a}$ & $24.0 \pm 6.2 \mathrm{a}$ \\
\hline PAHs + Tween $80+$ SA & $16.5 \pm 1.1 \mathrm{~b}$ & $3198.0 \pm 700.1 b$ & $152.7 \pm 42.4 \mathrm{c}$ & $4.1 \pm 0.9 \mathrm{a}$ & $1008.0 \pm 510.5 \mathrm{a}$ & $41.7 \pm 20.2 \mathrm{a}$ & $17.1 \pm 2.9 \mathrm{a}$ & $9.1 \pm 1.2 \mathrm{a}$ & $26.2 \pm 4.0 \mathrm{a}$ \\
\hline
\end{tabular}

Different lower case letters denote significant differences $(\mathrm{P}<0.05)$ between treatments in the same column. Abbreviation: PAHs $=$ $100 \mathrm{mg} / \mathrm{kg}$ of anthracene plus $100 \mathrm{mg} / \mathrm{kg}$ of fluoranthene; $\mathrm{SA}=$ salicylic acid.

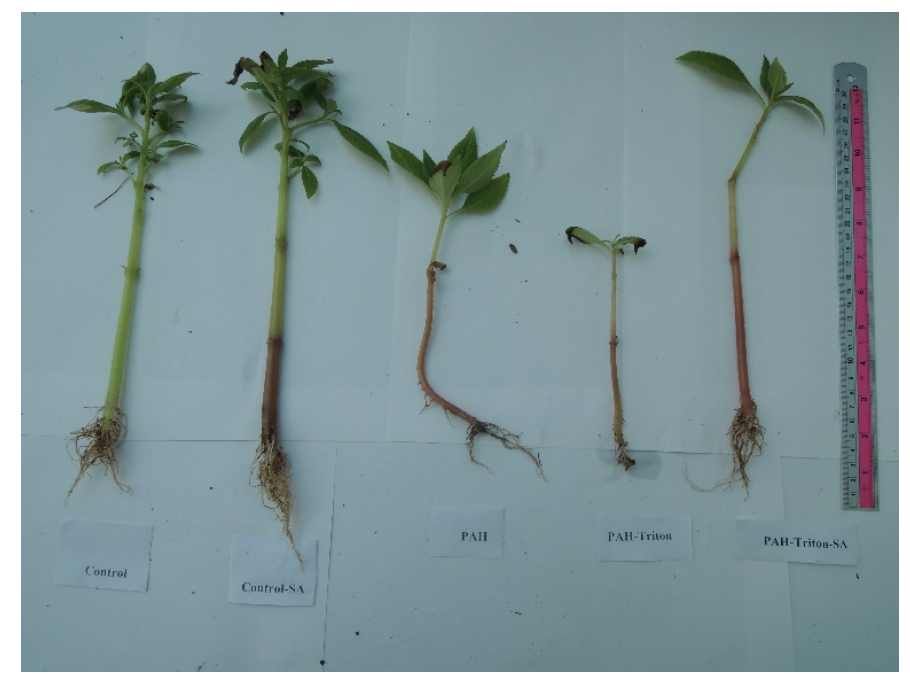

Figure $1 \mathrm{I}$. balsamina grown in non-contaminated soil and anthracene plus fluoranthene-contaminated soil receiving salicylic acid and Triton X-100 for 45 days. Abbreviation: PAHs $=100 \mathrm{mg} / \mathrm{kg}$ of anthracene plus $100 \mathrm{mg} / \mathrm{kg}$ of fluoranthene; $\mathrm{SA}=$ salicylic acid. 
http://wjst.wu.ac.th

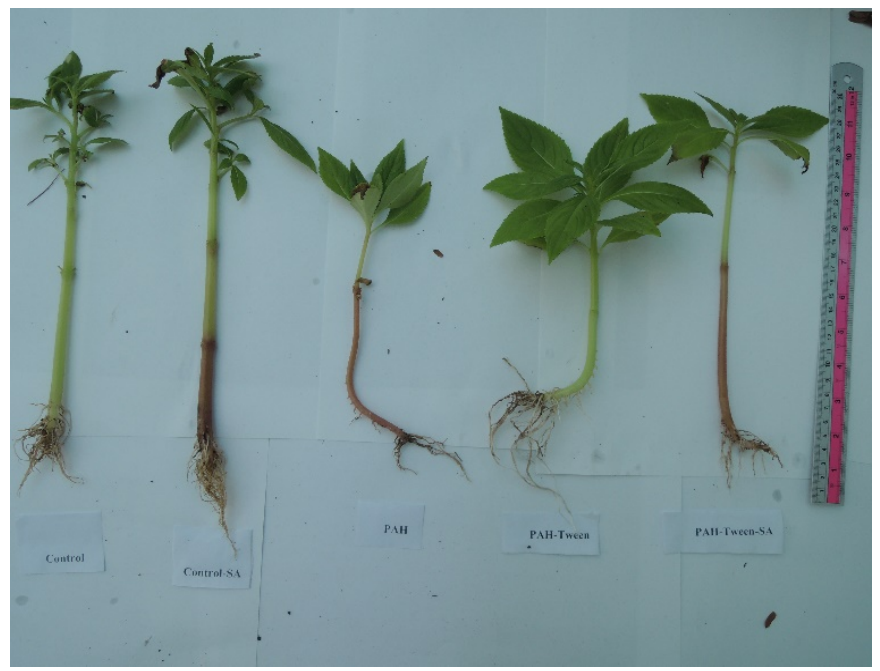

Figure 2 I. balsamina grown in non-contaminated soil and anthracene plus fluoranthene-contaminated soil receiving salicylic acid and Tween 80 for 45 days. Abbreviation: PAHs $=100 \mathrm{mg} / \mathrm{kg}$ of anthracene plus $100 \mathrm{mg} / \mathrm{kg}$ of fluoranthene; $\mathrm{SA}=$ salicylic acid.

The results in Table 3 show that the spraying of salicylic acid to non-contaminated soil did not increase the shoot growth of I. balsamina. The shoot length, shoot fresh weight, and shoot dry weight of I. balsamina grown in non-contaminated soil when receiving salicylic acid were $20.8 \mathrm{~cm}, 5990 \mathrm{mg}$ and $3198 \mathrm{mg}$, respectively. However, the shoot length, shoot fresh weight and shoot dry weight of $I$. balsamina grown in soil contaminated with anthracene plus fluoranthene and without receiving any amendments were only $12.6 \mathrm{~cm}, 1546 \mathrm{mg}$, and $79.9 \mathrm{mg}$, respectively. Moreover, the application of salicylic acid alone, Triton X-100 alone, Tween 80 alone or salicylic acid in combination with each surfactant did not increase the shoot growth of I. balsamina grown in anthracene plus fluoranthenecontaminated soil (Table 3). Besides, the root length, root fresh weight, and root dry weight of I. balsamina grown in non-contaminated soil or soil contaminated with anthracene plus fluoranthene were not significantly different from each other. Salicylic acid spraying did not increase the root growth (root length and root weight) of I. balsamina grown in non-contaminated soil and anthracene plus fluoranthenecontaminated soil. In addition, the application of Triton X-100 alone, Tween 80 alone or salicylic acid in combination with Triton X-100 or Tween 80 did not stimulate the root growth of I. balsamina. The root length, root fresh weight, and root dry weight of I. balsamina grown in non-contaminated soil and anthracene plus fluoranthene-contaminated soil in the presence or absence of amendments ranged from $3.1-6.4 \mathrm{~cm}, 520$ - $1690 \mathrm{mg}$, and 228 - $70.9 \mathrm{mg}$, respectively (Table 3).

The chlorophyll content in the leaves of I. balsamina grown in non-contaminated soil with or without receiving salicylic acid was not significantly different from that grown in anthracene plus fluoranthene-contaminated soil with or without receiving salicylic acid. As well, the chlorophyll contents in the leaves of I. balsamina grown in anthracene plus fluoranthene-contaminated soil when receiving salicylic acid alone, Triton X-100 alone, Tween 80 alone, or salicylic acid in combination with each surfactant amendment were not significantly different from that grown in soil without any amendments. The chlorophyll a, chlorophyll $\mathrm{b}$ and total chlorophyll contents in the leaves of $I$. balsamina grown in anthracene plus fluoranthene-contaminated soil in the presence of Triton X-100 or Tween 80 and receiving salicylic were around $15.4-17.1,8.5-9.1$, and $24.0-26.2 \mathrm{mg} / \mathrm{ml}$, respectively. Meanwhile, the chlorophyll $\mathrm{a}$, chlorophyll $\mathrm{b}$, and total chlorophyll contents in the leaves of $I$. balsamina grown in anthracene plus fluoranthene-contaminated soil when receiving salicylic acid alone, Triton X-100 alone or Tween 80 alone ranged from 8.0 - 14.0, $4.6-7.4$ and $13.1-21.3 \mathrm{mg} / \mathrm{ml}$, respectively (Table 3). In 
http://wjst.wu.ac.th

general, some surfactants were reported to be toxic to plant, especially to plant roots. The suppression or killing of plant roots by a surfactant have been reported in terrestrial plants, such as wheat [36]. Moreover, a suitable concentration for the surfactant application in agriculture could improve nutrient uptake by modulating the availability of the nutrients in the soil to the crop plant [37]. In this study, it seemed to be that Triton X-100 suppress the growth of I. balsamina and Tween 80 seemed to be stimulated the growth of I. balsamina when observed by the naked eye. However, this study did not determine nutrient uptake by I. balsamina and the presence of $1 \mathrm{X}$ CMC of Triton X-100 and 1X CMC of Tween 80 did not increase the growth (root length, root weight, shoot length, shoot weight, and chlorophyll contents) of I. balsamina in the phytoremediation experiment.

\section{Anthracene and fluoranthene removal from soil}

In soil without planting, the percentages of anthracene and fluoranthene remaining in the soil were $63.8 \%$ and $70.0 \%$ on day 45 of the experiment, respectively (Table 4 ). The application of salicylic acid alone, Triton X-100 alone or Tween 80 alone did not improve the anthracene and fluoranthene removal from contaminated soil, as about $60.4-72.6 \%$ of anthracene and $70.2-76.3 \%$ of fluoranthene remained in the soil on 45 days of the experiment. The application of salicylic acid together with Triton X-100 (47.1\% of anthracene remained) seemed to decrease the anthracene in the contaminated soil by the greatest extent compared to the other treatments of the unplanted soil. However, the application of salicylic acid in combination with Triton X-100 or Tween 80 did not stimulate the removal of fluoranthene from the contaminated soil (61.1 - 69.4\% of fluoranthene remained in the soil) (Table 4).

However, growing I. balsamina in anthracene plus fluoranthene-contaminated soil did not increase anthracene and fluoranthene removal from the soil. The percentage of anthracene and fluoranthene remaining in the planted soil without receiving salicylic acid or a surfactant was not significantly different when compared with unplanted soil under the same condition. About $77.4 \%$ of anthracene and $74.6 \%$ of fluoranthene remained in the planted soil without receiving salicylic acid or a surfactant (Table 4). Planting I. balsamina alone in contaminated soil was not suitable to be used in phytoremediation of anthracene and fluoranthene because the amount of anthracene and fluoranthene remaining in the soil planted with I. balsamina was not significantly different from unplanted soil. In addition, the number of anthracene or fluoranthene degraders in the soil in this study was not increased by cropping with I. balsamina. The number of anthracene degraders at the beginning of the experiment was $\log 1.7 \mathrm{cfu} / \mathrm{g}$, while the fluoranthene degraders were not found. The number of anthracene and fluoranthene degraders on the last day of each treatment were around $\log 0.9-1.4 \mathrm{cfu} / \mathrm{g}$ and $\log 0.9-1.8 \mathrm{cfu} / \mathrm{g}$, respectively (Table 5).

In planted soil, the application of salicylic acid, Triton X-100, Tween 80, and salicylic acid in combination with Triton X-100 or Tween 80 tended to decrease anthracene from the contaminated soil to a greater extent than the planted soil without receiving any amendment. The percentages of anthracene remaining in planted soil that received salicylic acid, Triton X-100, Tween 80, and salicylic acid in combination with Triton X-100 or Tween 80 were around 54.9 - $61.2 \%$ (Table 4). However, the application of salicylic alone, Triton X-100, Tween 80, or salicylic acid in combination with Triton X-100 or Tween 80 in planted soil did not increase the amount of fluoranthene removal from anthracene plus fluoranthene-contaminated soil. The percentages of fluoranthene remaining in planted soil that received salicylic acid, Triton X-100, Tween 80 , and salicylic acid in combination with Triton X-100 or Tween 80 were around $67.6-81.9 \%$ (Table 4). 
Table 4 Percentage of anthracene and fluoranthene remaining in anthracene and fluoranthene contaminated soil planted and unplanted with I. balsamina and receiving salicylic acid and surfactant for 45 days.

\begin{tabular}{lll}
\hline \multicolumn{1}{c}{ Treatment } & \multicolumn{1}{c}{ Anthracene } & \multicolumn{1}{c}{ Fluoranthrene } \\
\hline Non-planted soil & & \\
PAHs & $63.8 \pm 4.3 \mathrm{a}$ & $70.0 \pm 11.0$ \\
PAHs + Triton X-100 & $67.5 \pm 3.6 \mathrm{a}$ & $70.2 \pm 6.7$ \\
PAHs + Tween 80 & $60.4 \pm 5.2 \mathrm{ab}$ & $70.7 \pm 2.7$ \\
PAHs + SA & $72.6 \pm 4.7 \mathrm{a}$ & $76.3 \pm 12.2$ \\
PAHs + Triton X-100 + SA & $47.1 \pm 4.6 \mathrm{~b}$ & $61.1 \pm 8.7$ \\
PAHs + Tween 80+ SA & $59.7 \pm 3.4 \mathrm{ab}$ & $69.4 \pm 4.0$ \\
\hline Planted soil & $77.4 \pm 5.3 \mathrm{a}$ & \\
PAHs & $61.2 \pm 1.7 \mathrm{~b}$ & $74.6 \pm 1.9$ \\
PAHs + Triton X-100 & $58.0 \pm 2.0 \mathrm{~b}$ & $74.8 \pm 3.1$ \\
PAHs + Tween 80 & $57.8 \pm 7.5 \mathrm{~b}$ & $78.0 \pm 5.5$ \\
PAHs + SA & $54.9 \pm 3.3 \mathrm{~b}$ & $71.2 \pm 11.0$ \\
PAHs + Triton X-100+ SA & $55.8 \pm 3.6 \mathrm{~b}$ & $67.6 \pm 8.7$ \\
PAHs + Tween $80+$ SA & $\mathrm{ns}$ & $\mathrm{ns}$ \\
\hline Planted & $* *$ & $\mathrm{~ns}$ \\
\hline Amendment Application & $\mathrm{ns}$ \\
\hline Planted * Amendment Application & & $\mathrm{ns}$ \\
\hline
\end{tabular}

Different lowercase letters denote significant differences $(\mathrm{P}<0.05)$ between treatments in the same column. Abbreviation: PAHs $=100 \mathrm{mg} / \mathrm{kg}$ of anthracene plus $100 \mathrm{mg} / \mathrm{kg}$ of fluoranthene; SA = salicylic acid; ns $=$ non-significant difference $(P>0.05) ; * *=$ significant difference $(P<0.01)$.

Table 5 Number of anthracene and fluoranthene degraders in anthracene- and fluoranthene-contaminated soil planted and unplanted with I. balsamina and receiving salicylic acid and surfactant for 45 days. The number of anthracene degraders on day 0 was $\log 1.7 \pm 1.7 \mathrm{cfu} / \mathrm{g}$ but fluoranthene degraders were not found.

\begin{tabular}{lll}
\hline \multicolumn{1}{c}{ Treatment } & \multicolumn{1}{c}{$\begin{array}{c}\text { Anthracene degraders } \\
(\mathbf{l o g} \mathbf{c f u} / \mathbf{g})\end{array}$} & \multicolumn{1}{c}{$\begin{array}{c}\text { Fluoranthene degraders } \\
(\mathbf{l o g} \text { cfu/g) }\end{array}$} \\
\hline Non-planted soil & $1.4 \pm 1.4$ & 0 \\
PAHs & 0 & 0 \\
PAHs + Triton X-100 & $1.3 \pm 1.3$ & 0 \\
PAHs + Tween 80 & 0 & $1.8 \pm 1.8$ \\
PAHs + SA & 0 & 0 \\
PAHs + Triton X-100 + SA & 0 & 0 \\
PAHs + Tween 80 + SA & & \\
\hline Planted soil & $0.9 \pm 0.9$ & 0 \\
PAHs & 0 & $1.0 \pm 1.0$ \\
PAHs + Triton X-100 & 0 & 0 \\
PAHs + Tween 80 & 0 & 0 \\
PAHs + SA & 0 & 0 \\
PAHs + Triton X-100+ SA & $0.9 \pm 0.9$ & $0.9 \pm 0.9$ \\
PAHs + Tween $80+$ SA &
\end{tabular}

Abbreviation: PAHs $=100 \mathrm{mg} / \mathrm{kg}$ of anthracene plus $100 \mathrm{mg} / \mathrm{kg}$ of fluoranthene; $\mathrm{SA}=$ salicylic acid. 
http://wjst.wu.ac.th

In general, planted soil usually provided suitable conditions for the growth of microorganisms via root exudates as a carbon and nitrogen source. Root exudates can sometimes increase the extraction and removal of contaminants by plants [38] and can be affected by organic contaminants degradation by altering microbial catabolic gene expression [39]. However, growing I. balsamina in anthracene plus fluoranthene-contaminated soil in this study did not increase anthracene and fluoranthene removal from soil. The results of this study were different from previous research that reported I. balsamina could increase the removal of total petroleum hydrocarbons from contaminated soil derived from the Shengli Oil Field in Dongying City, Shandong Province, China. About 18.13 - $65.03 \%$ of the total petroleum hydrocarbons were degraded in planted soil after four months of the experiment, which is higher than natural degradation (only 10.20 - 35.61 \% of total petroleum hydrocarbons were degraded) [29]. Moreover, the ability of $I$. balsamina to remove naphthalene from organic contaminants that are contaminating soil was reported. Naphthalene was decreased in soil planted with I. balsamina by about $181.92 \%$. The main mechanism of naphthalene removal by I. balsamina may be phytoextraction because naphthalene was increased by $13.30 \%$ in the stem of $I$. balsamina cultivated at the contaminated sites [28]

The objective of the salicylic acid addition in this study was to alleviate the toxicity of anthracene and fluoranthene on the plants, but the contamination of anthracene and fluoranthene in the soil was not toxic to I. balsamina based on the plant growth parameters described before. However, salicylic addition in bioremediation did not only alleviate the toxicity of pollutants on plants, but salicylic acid has also been proven to be a metabolic inducer for PAH biodegradation due to the induction of nah gene expression in bacteria [40]. In this study, salicylic acid addition alone did not increase anthracene and fluoranthene removal from both planted and unplanted soil. There were variable results for salicylic acid application in PAH-contaminated soil. For example, addition of $100 \mathrm{mg} / \mathrm{l}$ salicylic acid to soil slurry containing $500 \mathrm{mg} / \mathrm{kg}$ phenanthrene and Pseudomonas putida ATCC 17484 increases the $30 \%$ phenanthrene biodegradation. However, the stimulation effect of salicylic acid decreased when the rhamnolipid were added together into soil slurry [41]. In contrast, salicylic acid addition in combination with Triton X-100 or Tween 80 only slightly enhanced anthracene removal in unplanted soil in this study; however, enhanced fluoranthene removal was not detected. In planted soil, addition with salicylic acid alone, Triton X-100 alone, Tween 80 alone or a combination of salicylic acid with synthetic surfactant (Triton X-100 or Tween 80) slightly enhanced anthracene removal but not fluoranthene. This may be due to Triton X-100 that could improve the availability of nutrients and anthracene to the anthracene degrader, which is already present in non-plant soil. However, the number of anthracene degraders and fluoranthene degraders in this study did not relate to the amount of anthracene and fluoranthene removal from the soil. This finding is not surprising because the activity of anthracene and fluoranthene degradation in soil may be from the synergistic effect between several microorganisms in the soil or the PAH degraders in this soil were unculturable strains.

The relationship between plant and soil microorganisms in this study was not obvious. The activity of anthracene degradation in this study may have come from indigenous microorganisms because anthracene removal was observed in both plant and non-plant soil. Moreover, anthracene was removed from the soil to a greater extent than fluoranthene. This may be due to fluoranthene having a higher molecular weight PAH with four aromatic rings and rendering it recalcitrant to degradation by microbial enzymes or other processes, such as volatilization, photooxidation and chemical oxidation, when compared with anthracene $[42,43]$. From the results of this study, we can conclude that phytoremediation results from using Triton X-100 or Tween 80 as amendments were variable. For example, Triton X-100 enhanced the initial removal of phenanthrene (initial concentration was $4.1 \mathrm{mg} / \mathrm{kg}$ ) and pyrene (initial concentration was $37.0 \mathrm{mg} / \mathrm{kg}$ ) from contaminated soil planted with Zea mays but did not affect phenanthrene and pyrene accumulation in plant biomass [23]. Tween 80 also stimulated the removal of pyrene (initial concentration was $300 \mathrm{mg} / \mathrm{kg}$ ) but not phenanthrene (initial concentration was $300 \mathrm{mg} / \mathrm{kg}$ ) from soil planted with Agropyron elongatum after 60 days of the experiment. About $79 \%$ of pyrene was removed from planted soil with the addition of $100 \mathrm{mg} / \mathrm{kg}$ of Tween 80 and only $61 \%$ of pyrene was removed from planted soil without Tween 80 addition [21]. 
http://wjst.wu.ac.th

\section{Conclusions}

I. balsamina was not a suitable plant species for anthracene and fluoranthene phytoremediation. Planting with this species did not enhance anthracene and fluoranthene removal from contaminated soil. Applications of salicylic acid alone, Triton X-100, or Tween 80 alone slightly increased the removal of anthracene but not fluoranthene. The appropriate way to remove anthracene from contaminated soil in this study was biostimulated with salicylic in combination with Triton X-100 without planting. The removal of PAHs in this study may be caused by the activity of indigenous microorganisms.

\section{Acknowledgements}

The authors gratefully acknowledge financial support from the Faculty of Science, Mahasarakham University (Financial Year 2018). We would like to thank Dr. Jolyon Dodgson, Faculty of Science, Mahasarakham University for his help in correcting the English of this manuscript. Authors have no conflict of interest to declare.

\section{References}

[1] J Wang, X Zhang, W Ling, R Liu, J Liu, F Kang and Y Gao. Contamination and health risk assessment of PAHs in soils and crops in industrial area of the Yangtze River Delta region, China. Chemosphere 2017; 168, 976-87.

[2] G Liua, J Niua, W Guoa, L Zhao, C Zhang, M Wang, Z Zhang and G Guo. Assessment of terrain factors on the pattern and extent of soil contamination surrounding a chemical industry in Chongqing, Southwest China. Catena 2017; 156, 237-43.

[3] S Suman, A Sinha and A Tarafdar. Polycyclic aromatic hydrocarbons (PAHs) concentration levels, pattern, source identification and soil toxicity assessment in urban traffic soil of Dhanbad, India. Sci. Total Environ. 2016; 545-546, 353-60.

[4] L Hu, X Shi, S Qiao, T Lin, Y Li, Y Bai, B Wu, S Liu, N Kornkanitnan and S Khokiattiwong. Source and mass inventory of sedimentary polycyclic aromatic hydrocarbons in the Gulf of Thailand: Implications for pathways and energy structure in SE Asia. Sci. Total Environ. 2017; 575, 982-95.

[5] S Pongpiachan, D Tipmanee, W Deelaman, J Muprasit, P Feldens and K Schwarzer. Risk assessment of the presence of polycyclic aromatic hydrocarbons (PAHs) in coastal areas of Thailand affected by the 2004 tsunami. Mar. Pollut. Bull. 2013; 76, 370-8.

[6] D Wang, J Ma, H Li and X Zhang. Concentration and potential ecological risk of PAHs in different layers of soil in the petroleum-contaminated areas of the Loess Plateau, China. Int. J. Env. Res. Pub. He. 2018; 15, 1785.

[7] Agency for Toxic Substances and Disease Registry (ATSDR). U.S. Department of Health \& Human. Services case studies in environmental medicine: Toxicity of polycyclic aromatic hydrocarbons (PAHs), Available at: https://www.atsdr.cdc.gov/csem/csem.asp?csem=13\&po=0, accessed July 2019.

[8] OO Olayinka, OH Adedeji and AR Ipeaiyeda. Determination of polycyclic aromatic hydrocarbons (PAHs) on selected dumpsites in Abeokuta Metropolis, SW, Nigeria. App. Envi. Res. 2015; 37, 3348.

[9] S Kuppusamy, P Thavamani, K Venkateswarlu, YB Lee, R Naidu and M Megharaj. Remediation approaches for polycyclic aromatic hydrocarbons (PAHs) contaminated soils: Technological constraints, emerging trends and future directions. Chemosphere 2017; 168, 944-68.

[10] J Li, Y Zheng, X Luo, Z Lin, W Zhang and X Wang. PAH contamination in Beijing's topsoil: A unique indicator of the megacity's evolving energy consumption and overall environmental quality. Sci. Rrp.UK 2016; 6, 33245.

[11] KS Patel, S Ramteke, Y Naik, BL Sahu, S Sharma, J Lintelmann and M Georg. Contamination of environment with polycyclic aromatic hydrocarbons in India. J. Environ. Prot. 2015; 6, 1268-78.

[12] AT Lawal. Polycyclic aromatic hydrocarbons: A review. Cogent Environ. Sci. 2017; 3, 1339841. 
http://wjst.wu.ac.th

[13] C Achten and JT Andersson. Overview of polycyclic aromatic compounds (PAC). Polycycl. Aromat. Comput. 2015; 35, 177-86.

[14] CC Azubuike, CB Chikere and GC Okpokwasili. Bioremediation techniques: Classification based on site of application: Principles, advantages, limitations and prospects. World J. Microb. Biot. 2016; 32, 180.

[15] K Somtrakoon, W Chouychai and H Lee. Comparing anthracene and fluorene degradation in anthracene and fluorene-contaminated soil by single and mixed plant cultivation. Int. J. Phytoremediat 2014; 16, 415-28.

[16] E Pilon-Smits. Phytoremediation. Annu. Rev. Plant Biol. 2005; 56, 15-39.

[17] YZ Gao, WT Ling, LZ Zhu, BW Zhao and QS Zheng. Surfactant-enhanced phytoremediation of soils contaminated with hydrophobic organic contaminants: Potential and assessment. Pedosphere 2007; 17, 409-18.

[18] X Liang, C Guo, C Liao, S Liu, LY Wick, D Peng, X Yi, G Lu, H Yin, H Lin and Z Dang. Drivers and applications of integrated clean-up technologies for surfactant-enhanced remediation of environments contaminated with polycyclic aromatics hydrocarbons (PAHs). Environ. Pollut. 2017; 225, 129-40.

[19] C Cuypers, T Pancras, T Grotenhuis and W Rulkens. The estimation of PAH bioavailability in contaminated sediments using hydroxypropyl-b-cyclodextrin and Triton X-100 extraction techniques. Chemosphere 2002; 46, 1235-45.

[20] X Liang, C Guo, Y Wei, W Lina, X Yi, G Lu and Z Dang. Cosolubilization synergism occurrence in codesorption of PAH mixtures during surfactant-enhanced remediation of contaminated soil. Chemosphere 2016; 144, 583-90.

[21] KY Cheng, KM Lai and JWC Wong. Effects of pig manure compost and nonionic-surfactant Tween 80 on phenanthrene and pyrene removal from soil vegetated with Agropyron elongatum. Chemosphere 2008; 73, 791-7.

[22] AS Ramamurthy and R Memarian. Phytoremediation of mixed soil contaminants. Water Air Soil Poll. 2012; 223, 511-8.

[23] C Liao, X Liang, G Lu, T Thai ,W Xu and Z Dang. Effect of surfactant amendment to PAHcontaminated soil for phytoremediation by maize (Zea mays L.). Ecotoxical. Environ. Saf. 2015; 112, $1-6$.

[24] E Olkowska, R Ruman and Ż Polkowska. Occurrence of surface active agents in the environment. J. Anal. Methods Chem. 2014; 2014, 769708.

[25] Q Guo, L Meng, PC Mao, YQ Jia and YJ Shi. Role of exogenous salicylic acid in alleviating cadmium-induced toxicity in Kentucky bluegrass. Biochem. Syst. Ecol. 2013; 50, 269-76.

[26] AP Singh, G Dixit, A Kumar, S Mishra, N Kumar, S Dixit, PK Singh, S Dwivedi, PK Trivedi, V Pandey, OP Dhankher, GJ Norton, D Chakrabarty and R Tripathi. A protective role for nitric oxide and salicylic acid for arsenite phytotoxicity in rice (Oryza sativa L.). Plant Physiol. Bioch. 2017; 15, 163-73.

[27] C Wang and Q Zhang. Exogenous salicylic acid alleviates the toxicity of chlorpyrifos in wheat plants (Triticum aestivum). Ecotoxical. Environ. Saf. 2017; 137, 218-24.

[28] Z Cai, Q Zhou, L Cheng, R Zhou, X Wang, J Tang, Q Zhang, J Liu, W Liu and J Yang. 2015. Enhanced Combination Methods for Phytoremediation of Petroleum Contaminated Soils by Impatiens balsamina L. Associated with the Indigenous Microorganism. Patent US2015/0104855 A1.

[29] Z Cai, Q Zhoua, S Penga and K Li. Promoted biodegradation and microbiological effects of petroleum hydrocarbons by Impatiens balsamina L. with strong endurance: A critical review. $J$. Hazard Mater. 2010; 183, 731-7.

[30] MZ Nawahwi, KM Aziz, SM Mohamed, SM Shariff, NA Hasan, ATA Rahman, HA Malek, MI Rahim, MNZ Taib and MA Abdullah. Phytoremediation potential of Impatiens balsamina towards naphthalene contaminated soil in different parts of plant. American-Eurasian J. Agric. Environ. Sci. $2014 ; 14,610-4$. 
http://wjst.wu.ac.th

[31] Z Chang, X Chen and Y Peng. The adsorption behavior of surfactant on mineral surfaces in the presence of electrolytes. Miner. Eng. 2018; 121, 66-76.

[32] XD Huang, Y El-Alawi, DM Penrose, BR Glick and BM Greenberg. Response of three grass species to creosote during phytoremediation. Environ. Pollut. 2004; 130, 453-63.

[33] MA Providenti, CW Greer, H Lee and JT Trevors. Phenanthrene mineralization by Pseudomonas sp. UG14. World J. Microb. Biot. 1995; 39, 637-43.

[34] T Ivanković and J Hrenović. Surfactants in the environment. Arh. Hig. Rada. Toksikol. 2010; 61, 95-110.

[35] K Jahan, S Balzer and P Mosto. Toxicity of nonionic surfactants. WIT Trans. Ecol. Environ. 2008; 110, 281-290.

[36] S Rebello, AK Asok, S Mundayoor and MS Jisha. Surfactants: Chemistry, Toxicity and Remediation. In: E Lichtfouse (Eds.). Pollutant Diseases, Remediation and Recycling, Environmental Chemistry for a Sustainable World 4. Springer International Publishing, Switzerland, 2013, p. 277-320.

[37] A Trinchera and V Baratella. Use of a non-ionic water surfactant in lettuce fertigation for optimizing water use, improving nutrient use efficiency, and increasing crop quality. Water 2018; 10, 613.

[38] A Cristaldi, GO Conti, EH Jho, P Zuccarello, A Grasso, C Copat and M Ferrante. Phytoremediation of contaminated soils by heavy metals and PAHs. A brief review. Environ. Tech. Innovati. 2017; 8, 309-26.

[39] H Lu, J Sun and L Zhu. The role of artificial root exudate components in facilitating the degradation of pyrene in soil. Sci. Rep. 2017; 7, 7130.

[40] D Ghosal, S Ghosh, TK Dutta and Y Ahn. Current state of knowledge in microbial degradation of polycyclic aromatic hydrocarbons (PAHs): A review. Front. Microbiol. 2016; 7, 1369.

[41] A Gottfried, N Singhal, R Elliot and S Swift. The role of salicylate and biosurfactant in inducing phenanthrene degradation in batch soil slurries. Appl. Microbiol. Biotechnol. 2010; 86, 1563-71.

[42] JJ Ortega-Calvo, MC Tejeda-Agredano, C Jimenez-Sanchez, E Congiu, R Sungthong, JL NiquiArroyo and $\mathrm{M}$ Cantos. Is it possible to increase bioavailability but not environmental risk of PAHs in bioremediation? J. Hazard Mater. 2013; 261, 733-45.

[43] T Kadri, T Rouissi, SK Brar, M Cledon, S Sarma and M Verma. Biodegradation of polycyclic aromatic hydrocarbons (PAHs) by fungal enzymes: A review. J. Environ. Sci. 2017; 51, 52-74. 